\title{
ON THE BIOLOGY OF AMEROSEIUS DENDROVAGANS (ACARI, MESOSTIGMATA, AMEROSEIIDAE)
}

CARLOS A. H. FLECHTMANN ?

\section{ABSTRACT}

Results of observations on the feeding habit and biology of Ameroseius dendrovagans Flechtmann \& Flechtmann are given.

\section{INTRODUCTION}

Bark beetles (Coleoptera, Scolytidae) are of economic importance in Pinus timber production. Many mites are frequently observed in the galleries of these beetles and the references to their taxonomic data are too numerous to be included in this introduction.

However, information on the biology and feeding habits of most mite species associated with Scolytid galleries is scarce.

Examination of available literature yielded no information on the biology of mites of the genus Ameroseius Berlese, 1903. As of their feeding habits, Karg (1971) in his revision, informs that members of the family Ameroseiidae Evans, 1963 are found in cultivated soil, meadows and forest soil, mainly in the superficial litter and humus layers, and in stored food, where they probably feed on fungi and mites of the genus Tyrophagus. The known species of Ameroseius have been found in a variety of habitats, such as soil, rotten potatoes, in ant and wasp nests, damp residences, on mosses, in horse, cow and rabbit droppings, decaying organic matter, on bark, in hay and house dust. Ameroseius plumigerus (Oudemans, 1930) feeds on "molds". A. longitrichus Hirschmann, 1963 was collected from galleries of several species of bark beetles in firs and A. ulmi Hirschmann, 1963 in galleries of Scolytus scolytus in elm in Europe. Moser (1975) reports A. longitrichus from the galleries of the southern pine beetle, Dendroctonus frontalis Zimmermann; however, nymphs, females and males of this mite did not attack either eggs, neither larvae nor pupae of the beetle in laboratory tests.

This paper reports on the biology and feeding habits of Ameroseius dendrovagans Flechtmann \& Flechtmann, 1985 under laboratory conditions.

\section{MATERIALS AND METHODS}

Specimens of $A$. dendrovagans were collected from galleries of Xyleborus sp. (Coleoptera, Scolytidae) and under bark of Pinus sp. in sections of logs originating from Sacramento, Minas Gerais.

The mites were reared in plastic containers $(5 \mathrm{~cm}$ in diameter $\times 4 \mathrm{~cm}$ height) with a layer of a 9:1 mixture of Plaster of Paris and activated charcoal of ca $7 \mathrm{~mm}$ and fed with the fungus Trichoderma sp.

The fungus, obtained from the same habitat of the mite, was reared in Petri dishes on PDA (potato-dextrose-agar) medium. Discs of ca $1.5 \mathrm{~cm}$ in diameter were excised from this substrate and containing cultures with many conidia and transferred to the mite rearing chambers, which were maintained at ambient temperature (ranging from $20-25^{\circ} \mathrm{C}$ ) and examined daily under a stereoscope. 


\section{RESULTS AND DISCUSSION}

Feeding habits: all post embryonic stages of $A$. dendrovagans fed actively on the conidia of Trichoderma sp; occasionally a female was observed nibbling on the fungus mycelium. On this diet the mite was reared through 25 consecutive generations. Not all of the ingested conidia are, however, digested. Transferring mite feces to PDA medium resulted in some Trichoderma colonies, indicating that some conidia can pass unaffected through the mite's digestive system. Thus, $A$. dendrovagans disperses Trichoderma sp conidia in two different ways: adherent to its body and through its feces. The mite was also observed feeding on Trichoderma conidia in its natural habit, that is, under the bark and inside the beetle galleries.

Development: $A$. dendrovagans is an oviparous species. The eggs are relatively large, average of $187 \times 153 \mu \mathrm{m}$, about one third the volume of the female. Three females, whose total egg laying was assessed, produced 120,118 and 52 eggs in 13,10 and 6 days respectively. The eggs were laid isolated or in clusters, apparently in relation to the amount of available conidia. When a female was feeding on a patch with a large number of conidia, eggs were laid in clusters; when it had to roam about to seek for conidia, eggs were laid individually. The incubation period for the eggs varied from 48 hours to 72 hours.

From the eggs emerged hexapod larvae; after feeding, the larva became inert and from this form emerged the protonymph which had acquired a fourth pair of legs. The duration of the larval stage was 24 hours. The protonymph was followed by a deutonymph and the adult stage. Each rymphal stage had a 24 hour duration. Larvae and nymphs were whitish and presented a soft integument. They were an easy prey for mites of the family Ascidae, also present in the bark beetle galleries. These mites did not, however, attack the adults of $A$. dendrovagans, which were brownish in colour and had a harder integument. In life, the adults kept the dorsal setae slightly erect and pointing backwards, probably in a defense attitude.

The males apparently have a mean of detecting the sex of the quiescent deutonymph, just prior to its moult. They were observed in a "guarding" attitude over the deutonymph; immediately after the emergence, the female was fertilized. This "guarding" and prompt mating is common among members of the family Tetranychidae and in the Tarsonemidae the male even carries the resting nymphal stage; it is probably reported for the first time in the Mesostigmata.

Females started ovipositing 24-48 hours after mating; non fertilized females did not lay eggs. Data from the observations of the development of the offspring of 3 females are presented in table I.

Table I - Offspring of 3 females of Ameroseius dendrovagans

\begin{tabular}{cccccc}
\hline $\begin{array}{c}\text { Female } \\
\text { no. }\end{array}$ & $\begin{array}{c}\text { Longevity } \\
\text { of females } \\
\text { (days) }\end{array}$ & $\begin{array}{c}\text { Egg laying } \\
\text { period } \\
\text { (days) }\end{array}$ & $\begin{array}{c}\text { Total no. } \\
\text { of eggs }\end{array}$ & $\begin{array}{c}\text { No. of } \\
\text { adults } \\
\text { reared }\end{array}$ & $\begin{array}{c}\text { Sexual ratio } \\
\text { (female: } \\
\text { males) }\end{array}$ \\
\hline 1 & 14 & 13 & 120 & 97 & $8: 89$ \\
2 & 11 & 10 & 118 & 94 & $9: 85$ \\
3 & 7 & 6 & 52 & 37 & $2: 35$ \\
\hline
\end{tabular}

We are grateful to Dr. Evoneo Berti F., Dept. of Entomology, for the collection of the $\log$ sections and his stimmulating remarks; to Dr. Tasso 
L. Kruegner, Dept. of Phytopathology, for the identification of the fungus and for its rearing media.

This research was carried out in the Dept. of Zoology, ESALQ, Univ. of São Paulo. The advisor was Dr. Carlos H. W. Flechtmann.

\section{REFERENCES}

Karg, W., 1971. 59. Teil. Acari (Acarina), Milben. Unterordnung Anactinochaeta (Parasitiformes). Die freilebenden Gamasina (Gamasides), Raubmilben. In: Dahl, F. \& F. Peus, Die Tierwelt Deutschlands. G. Fischer, Jena, 1-475. Moser, J. C., 1975. Mite Predators of the Southern Pine Beetle. Ann. ent. Soc. Am. 68(6): 1113-1116. 